\title{
Retrofitting of Brick Masonry Panels with Glass Fibre Reinforced Polymers
}

\author{
H. A. Khan ${ }^{1}$, P. Roy ${ }^{2}$ and R. P. Nanda ${ }^{3}$ \\ ${ }^{\text {I }}$ PhD.Research Scholar, Dept. of Civil Engineering, NIT Durgapur, India) \\ ${ }^{2}$ (PhD.Research Scholar, Dept. of Civil Engineering, NIT Durgapur, India) \\ ${ }^{3}$ (Associate Professor, Dept. of Civil Engineering, NIT Durgapur, India)
}

\begin{abstract}
The in-plane performances of brick masonry panels with different retrofitting patterns using glass fibre reinforced polymers (GFRP), have been studied under diagonal compression test. The panels were retrofitted on one side and both sides with diagonal and cross geometrical pattern. It was observed that the inplane strength of the retrofitted patterns increased from $18.05 \%$ to $69.84 \%$ when compared to un- retrofitted specimens. The retrofitted specimens increased the failure load from $26.6 \mathrm{kN}(U R)$ to $69.5 \mathrm{kN} F R P$ retrofitting also increased the diagonal shear strength. It was observed that diagonal shear strength of the retrofitted panels increased from $0.25 \mathrm{MPa}$ to $0.38 \mathrm{MPa}$ when retrofitted with one side, while it goes up to $0.65 \mathrm{MPa}$ when retrofitted with both side as compared to un-retrofitted specimens. Further, it also observed that the panel with cross retrofitting showed more efficiency in terms of shear strength, in-plane strength, stiffness and deformation capacity. This experimental study demonstrates the effectiveness of GFRPs as new strengthening technology for unreinforced brick structures.
\end{abstract}

Keywords: Diagonal compression test, GFRP, In-plane strength, Masonry panel, Retrofitting.

\section{Introduction}

Brick masonry is one of the most popular and suitable construction for housing purposes in almost all developing countries including China, India, Iran, Turkey etc. There are innumerable advantages of masonry construction over other of contemporary construction types, namely, reinforced concrete and steel, with respect to thermal comfort, sound control, less formwork, easy and inexpensive repair, use of locally available materials, the needof less skilled labour, less engineering intervention, etc. However, poor seismic withstand capacity is a major hindrance for its use in seismically active regions [1]. The majority of Un-Reinforced Masonry (URM) buildings have been constructed with little or no seismic requirement. URM walls have two possible failure mechanisms under seismic loading: in-plane and out-of-plane. The in-plane shear failure mode is the most important in-plane damage mode in URM walls under earthquake loading. Past researches show that during an earthquake, the predominant failure mode is shear [2]. The principal in-plane failure mechanisms (see Fig.1) of URM walls subjected to earthquake actions are as follows [3\&4].

a. Shear failure. It is a typical mode of failure of masonry wall subjected to seismic loads, and it can take place where the principal tensile stresses, developed in the wall under a combination of vertical and horizontal loads, exceeds the tensile strength of masonry.

b. Sliding failure. In the situation of low vertical load and poor quality mortar, seismic loads frequently cause shearing of wall causing sliding of the upper part of the wall at one of the horizontal mortar joints.

c. Rocking failure and toe-crushing failure. In the case of high moment/shear ratio or improved shear resistance, the wall may be set into rocking motion or toe crushing depending on the level of the applied normal force.

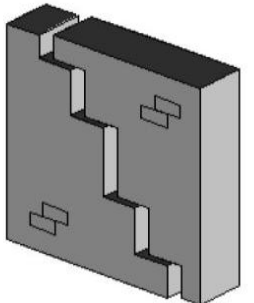

(a)

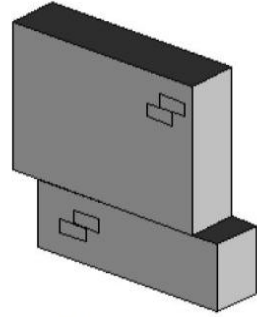

(b)

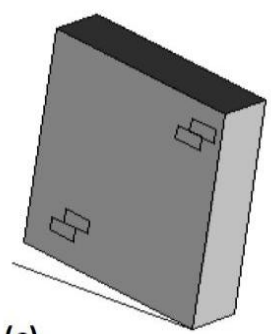

(c)

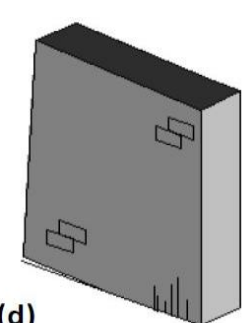

(d)

Fig.1. In-plane failure mechanisms of un-reinforced brick walls (a) Shear failure. (b) Sliding failure, (c) Rocking failure, (d) Toe-crushing failure. 
There are various techniques for retrofitting of existing URM buildings in order to increase their collapse time under seismic loading such as the application of shotcrete, steel reinforcement, stitching and grout/epoxy injection, bamboo reinforcement as external reinforcement, post-tensioning, confinement, centre core, mesh reinforcement etc [5\&6]. There are many disadvantages of these techniques such as high application time, available space reduction, occupancy disturbance, building operation disruption and affecting the aesthetics of the existing wall. Fibre reinforced polymer (FRP) retrofitting diminishes most of these problems. In addition to this, FRP strengthening is highly durable and cost-effective. Moreover, FRP has high strength to stiffness ratio. However, there are some disadvantages too of FRP strengthening; removal is extremely difficult; the resins used for bonding are flammable and the resin slowly becomes brittle, the long-term reliability of FRPs is largely unproven. Shear reinforcement technique had been examined using FRP with different configurations. The shear strength of strengthened wall panels was observed much more than that of the un-retrofitted specimens under diagonal tension [7].Many researchers have used FRP strengthening to increase the in-plane strength and strain capacity of masonry walls. FRP retrofitted in-plane loaded URM walls showed largely increased shear strength [8]. The peak strength of CFRP retrofitted masonry panels were found higher than unretrofitted, PP-band retrofitted and, FRP + PP-band retrofitted wallets [9]. The main objective of this paper is to assess the in-plane shear performance of un-retrofitted and retrofitted brick walls using GFRP with different patterns experimentally. To obtain a diagonal shear failure mode of masonry wall, force can be applied along diagonal of masonry panel with the help of steel loading shoe. In the experimental work; six brick panels were tested for the diagonal tension (shear) test (ASTM E519) to simulate the in-plane shear failure mode [10].

\section{Experimental Programme}

This experimental program investigates the efficiency and effectiveness of GFRP retrofitting technique to improve the in-plane performance of unreinforced brick masonry panels. Six solid clay brick masonry panels were tested for diagonal compression test. Different retrofitting configurations have been used. Properties of constituents of masonry were determined experimentally. The masonry panels consisted of brick and mortar joints. The materials used were representative of the materials used in existing masonry buildings in India. As the $1^{\text {st }}$ class traditional solid clay bricks are well burnt moulded bricks and have a uniform length, width, shape and well-defined edges; used in panels. The Dimension of brick is $250 \mathrm{~mm} \times 125 \mathrm{~mm} \times 75 \mathrm{~mm}$. Bricks were cleaned and soaked in water before use. In order to obtain the compressive strength of brick, six bricks were tested for compression test as per IS 3495: 1992 (Table 3) [11]. Bricks were bonded together by means of mortar, consisted of one part cement and four part sand; by volume. In order to obtain a characteristic compressive strength, at an age of 28 days, six $50 \mathrm{~mm}$ cube mortar were tested as per ASTM C109/ C109 M, (Table 3) [12]. The water quantity added to the dry mixture was determined to ensure a good workability of the fresh mortar. Fibre Reinforced Polymer (FRP) is a good reinforcing material. Use of FRPs has been vastly applied in the research programmes. FRPs consist of high strength fibres fixed in a resin matrix. The fibres are stronger than steel in the longitudinal direction and generally weak lateral direction. Generally, FRP shows no ductile behaviour, hence, the stress-strain behaviour can be considered as a linear elastic up-to failure.GFRP (Glass Fibre Reinforced Polymer) are used in the panels. GFRP has a very high strength to weight ratio. GFRP is unaffected by acid rain, salts, and most chemicals. GFRP is an engineered material composed of a polyester or epoxy resin, reinforced with glass fibres. In previous researches, retrofit of FRP was able to reduce the inherent variabilityof URM. In this study, one specimen was kept unreinforced and six specimens were strengthened, with different strengthening configurations, by a one layer of GFRP using Epoxy Resin with a mixture of hardener 1:10 by volume. The materials property of GFRP and Epoxy Resin are given in Table 1 and Table 2:

Table.1. Material properties of GFRP

\begin{tabular}{|l|l|l|l|l|l|l|l|}
\hline Material & $\begin{array}{l}\text { Tensile } \\
\text { strength } \\
(\mathrm{MPa})\end{array}$ & $\begin{array}{l}\text { Young's } \\
\text { modulus } \\
(\mathrm{GPa})\end{array}$ & $\begin{array}{l}\text { Tensile } \\
\text { modulus } \\
(\mathrm{GPa})\end{array}$ & $\begin{array}{l}\text { Bending } \\
\text { strength } \\
(\mathrm{MPa})\end{array}$ & $\begin{array}{l}\text { Bending } \\
\text { modulus } \\
(\mathrm{GPa})\end{array}$ & $\begin{array}{l}\text { Compressive } \\
\text { strength }(\mathrm{MPa})\end{array}$ & $\begin{array}{l}\text { Ultimate } \\
\text { Elongation } \\
(\%)\end{array}$ \\
\hline GFRP & 2400 & 70 & 7800 & 204 & 6770 & 900 & 2 \\
\hline
\end{tabular}

Table.2. Material properties of Epoxy

\begin{tabular}{|l|l|l|l|l|l|l|}
\hline Material & $\begin{array}{l}\text { Specific } \\
\text { gravity }\end{array}$ & $\begin{array}{l}\text { Tensile } \\
\text { Strength } \\
(\mathrm{MPa})\end{array}$ & $\begin{array}{l}\text { Tensile } \\
\text { shear } \\
\text { bond } \\
\text { strength } \\
(\mathrm{MPa})\end{array}$ & $\begin{array}{l}\text { Compressive } \\
\text { Strength } \\
(\mathrm{MPa})\end{array}$ & $\begin{array}{l}\text { Compressive } \\
\text { shear bond } \\
\text { strength } \\
(\mathrm{MPa})\end{array}$ & $\begin{array}{l}\text { Compressive } \\
\text { elasticity } \\
\text { modulus (MPa) }\end{array}$ \\
\hline Epoxy & 1.4 & 20 & 9.6 & 50 & 21 & 1.5 \\
\hline
\end{tabular}


To determine the average compressive strength of the masonry materials, compressive strength tests were conducted on bricks, mortar and masonry. Six bricks were tested and average compressive strength of brick was found $9.43 \mathrm{MPa}$. Six $50 \mathrm{~mm}$ cube were tested and average compressive strength of mortar was found 4.46 MPa. Six masonry prisms, each consisting of 3 bricks joined together with $12.5 \mathrm{~mm}$ mortar, were prepared and cured for 28 days. The length, width and height of prisms were $250 \mathrm{~mm}, 125 \mathrm{~mm}$ and $250 \mathrm{~mm}$, respectively. The average compressive strength of masonry prism was found 3.41 $\mathrm{MPa}$. The results are given in Table 3 .

Table.3. Properties of materials used in experiment

\begin{tabular}{|l|l|l|l|}
\hline Test & $\begin{array}{l}\text { Brick compressive } \\
\text { strength }(\mathrm{MPa})\end{array}$ & $\begin{array}{l}\text { Mortar cube Compressive } \\
\text { strength }(\mathrm{MPa})\end{array}$ & $\begin{array}{l}\text { Masonry prism compressive } \\
\text { strength }(\mathrm{MPa})\end{array}$ \\
\hline Specimen & 9.90 & 4.44 & 3.40 \\
\hline 2 & 9.80 & 4.45 & 3.39 \\
\hline 3 & 9.50 & 4.67 & 3.45 \\
\hline 4 & 9.20 & 4.56 & 3.38 \\
\hline 5 & 8.98 & 4.32 & 3.42 \\
\hline 6 & 9.20 & 4.31 & 3.40 \\
\hline Average & 9.43 & 4.46 & 3.41 \\
\hline
\end{tabular}

Six masonry panels, having dimension $600 \mathrm{~mm} \times 600 \mathrm{~mm} \times 125 \mathrm{~mm}$ were constructed in the laboratory environment. The thickness of mortar bed joints and head joints were kept $12.5 \mathrm{~mm}$ and $10 \mathrm{~mm}$ respectively. Each panel is built with 7 courses of brick. All test specimens were cured for at least 28 days before the application of GFRP.Out of them, two panel was kept un-retrofitted, named as UR, and considered as a reference specimen. Remaining panels were retrofitted with GFRP. The thickness of GFRP is $0.5 \mathrm{~mm}$ and width of GFRP wrapping strip was taken as $75 \mathrm{~mm}$. GFRP was wrapped in one layer on all retrofitted panels. The application of GFRP was a simple and fast operation. Epoxy resin adhesive mixed with hardener was used to wrap the GFRP. Extensive care was taken for the surface preparation before wrapping since premature debonding of FRP can occur due to the irregular surface or any gap between FRP and masonry. Two patterns, Diagonal and Cross, were used as strengthening configurations (see Fig. 2.). For each pattern, two specimen was retrofitted in one side and two specimen was retrofitted in both sides. The details of strengthening scheme and the labelling of the specimens with their patterns are shown in Table 4.

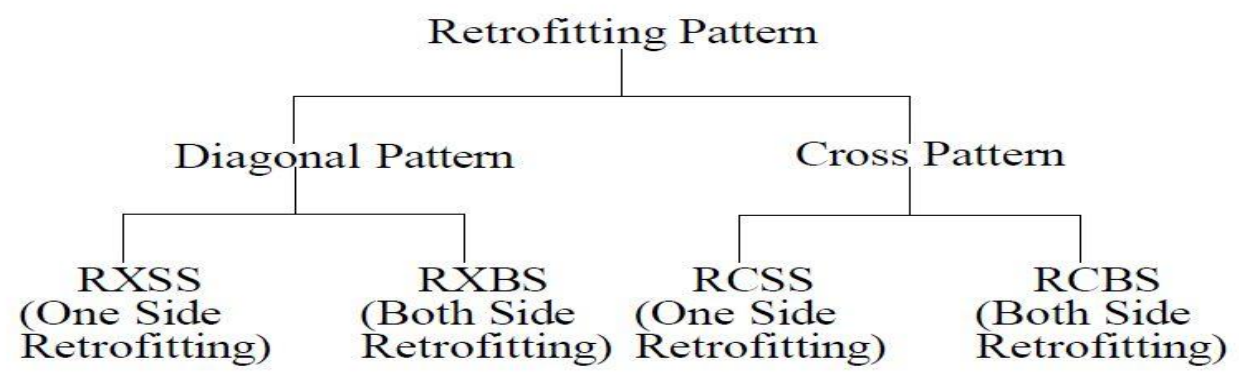

Fig.2. Labelling details with respect to retrofitting pattern

Table.4. Retrofitting pattern and scheme of specimens

\begin{tabular}{|l|l|l|l|l|l|}
\hline Retrofitting Pattern & Specimen & $\begin{array}{l}\text { Strengthening scheme } \\
\text { (See Fig.3.) }\end{array}$ & $\begin{array}{l}\text { Total area of } \\
\text { reinforcement } \\
\left(\mathrm{m}^{2}\right)\end{array}$ & $\begin{array}{l}\text { Reinforcement to } \\
\text { total area } \\
(\%)\end{array}$ \\
\hline- & UR & - & - & - \\
\hline $\begin{array}{l}\text { One Side } \\
\text { Retrofitted }\end{array}$ & Diagonal & RXSS & $\begin{array}{l}\text { Wrapped 2 diagonally } \\
\text { GFRP strips on one side }\end{array}$ & 0.12 & 16.67 \\
\cline { 2 - 7 } & Cross & RCSS & $\begin{array}{l}\text { Wrapped two GFRP strips } \\
\text { horizontally @ 200 mm } \\
\text { c/c and two GFRP strips } \\
\text { vertically @ 200 mm c/c } \\
\text { on one side }\end{array}$ & 25 & \\
\hline $\begin{array}{l}\text { Both side } \\
\text { retrofitted }\end{array}$ & Diagonal & RXBS & $\begin{array}{l}\text { Wrapped 2 diagonally } \\
\text { GFR strips per side on } \\
\text { both sides }\end{array}$ & & 33.33 \\
\hline
\end{tabular}




\begin{tabular}{|l|l|l|l|l|l|}
\hline Cross & RCBS & $\begin{array}{l}\text { Wrapped two GFRP strips } \\
\text { horizontally @ 200 mm } \\
\text { c/c and two GFRP strips } \\
\text { vertically @ 200 mm c/c } \\
\text { on both sides }\end{array}$ & 50.36 & \\
\hline
\end{tabular}

Six panels were tested at the Digital Dynamic Actuator Laboratory in Civil Engineering Department, National Institute of Technology, Durgapur (NITD). Forces and displacements were monitored and measured using the provided devices included in the Dynamic Actuator during the tests. Data collected from these tests permit evaluation of performance parameters of the specimens at different loading conditions. The actuator is manufactured by HEICO and has a maximum load capacity of $100 \mathrm{kN}$. The dynamic actuator is a highly advanced system with the fully computer controlled operation and also suitable for static loading applications. An inline coaxially mounted LVDT is fitted in the actuator to measure the displacement of the actuator and also run the system in displacement control mode. The servo valve is fixed to the actuator. Hydraulic power supplies are compact in design and are suitable for the supply of required flow and pressure for the actuation of the actuator to carry out various tests as per different standard for dynamic/static tests. It has an oil tank of adequate capacity, a pump powered by a three phase motor. It includes all the accessories like return line filter, oil level, relief valve, pressure gauge, Bye pass valve in case of clogging of the filter etc. Anti-vibration mountings are provided as standard along with the HPS. A schematic test setup of diagonal compression test is shown in Fig.3. The load was applied to all specimens at a constant rate of $0.005 \mathrm{~mm} / \mathrm{sec}$ along one diagonal of the panels with the help of steel loading shoes under displacement control mode. Two steel loading shoes are constructed in accordance with ASTM E-519.

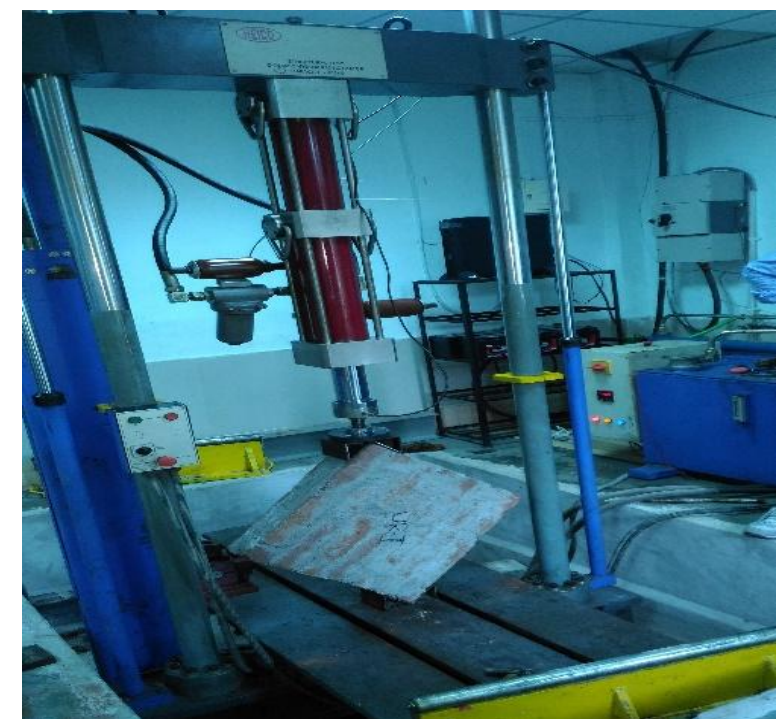

Fig.3. Servo Hydraulic Dynamic-Static Actuator

\section{Observation And Results}

The summary of the behaviour, crack pattern and failure mode, shear strength of the test panels subjected to diagonal compression tests is given in this section. The unreinforced specimen (UR) was failed by sliding along mortar bed joint as shown in Fig.4 (a). Maximum crushing load, used as a reference value for comparison with the rest strengthened specimens results, is $26.6 \mathrm{kN}$. The ratio of the weight to the load-bearing capacity for the unreinforced specimens is $3.2 \%$. For RXSS(Fig.4 b), the crack began near support in mortar head joint and it propagated through bed joint, brick and head joint. In RCSS (Fig.4 c), crack initiated due to diagonal tension in joints and followed by crushing of brick and pull out of GFRP strips. In RXBS, crack initiated in mortar joint near support and propagated through bed joint. Crushing of brick and pull out of GFRP occurred due to diagonal tension. In RCBS (Fig.4 d), the crack started in the head joint near support and a sudden failure occurred diagonally with the crushing of brickand pull out of GFRP strips. The Failure mode of each panel is shown in Fig.4 and the maximum crushing load and displacement is given in Table 5. 
Table.5. Crushing load and failure modes of the panels

\begin{tabular}{|c|c|c|c|c|c|}
\hline $\begin{array}{c}\text { Retrofitting } \\
\text { pattems }\end{array}$ & Specimen & $\begin{array}{c}\text { Average } \\
\text { Crushing } \\
\text { Load (KN) }\end{array}$ & $\begin{array}{c}\text { Average } \\
\text { Displacement } \\
\text { at } \\
\text { Crushing } \\
\text { Load (mm) }\end{array}$ & $\begin{array}{c}\text { Ratio of } \\
\text { weight to } \\
\text { load } \\
\text { Bearing } \\
\text { capacity (\%) }\end{array}$ & Failure mode \\
\hline- & UR & 26.6 & 5.5 & 3.2 & $\begin{array}{c}\text { Splitting along bed joint } \\
\text { through head joint }\end{array}$ \\
\hline $\begin{array}{c}\text { One side } \\
\text { Retrofitted }\end{array}$ & RXSS & 36.4 & 6.2 & 2.3 & Shear failure occurred. \\
\cline { 2 - 6 } & RCSS & 40.0 & 6.6 & 2.1 & $\begin{array}{c}\text { Crushing of brick and tear } \\
\text { of GFRP strip. }\end{array}$ \\
\hline $\begin{array}{c}\text { Both side } \\
\text { Retrofitted }\end{array}$ & RXBS & 52.2 & 6.4 & 1.6 & $\begin{array}{c}\text { Crushing of brick and tear } \\
\text { of GFRP strip. }\end{array}$ \\
\cline { 2 - 6 } & RCBS & 69.5 & 8.5 & 1.2 & $\begin{array}{c}\text { Splitting failure occurred } \\
\text { diagonally with crushing of } \\
\text { brick and tear of GFRP } \\
\text { strips }\end{array}$ \\
\hline
\end{tabular}

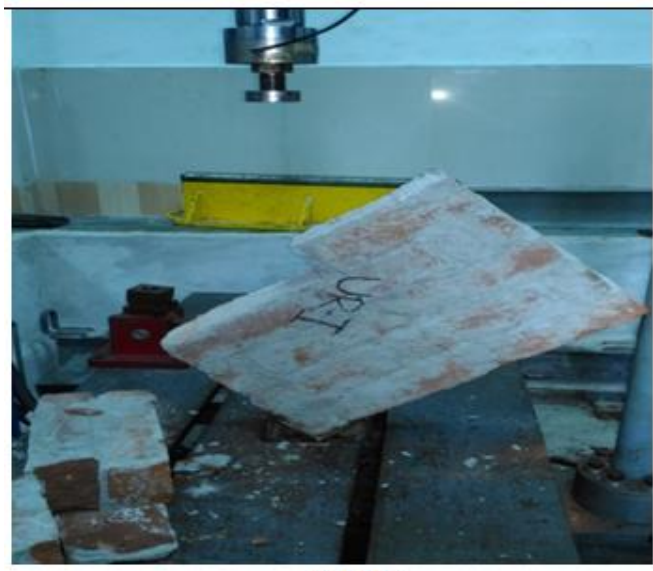

(a) UR

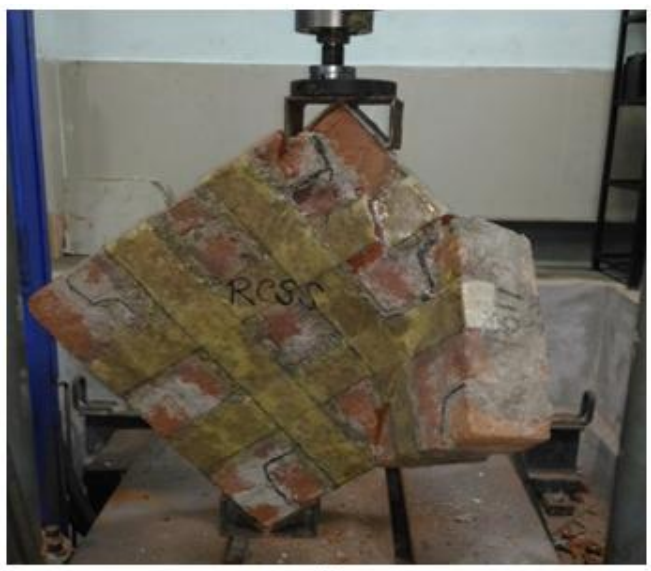

(c) RCSS

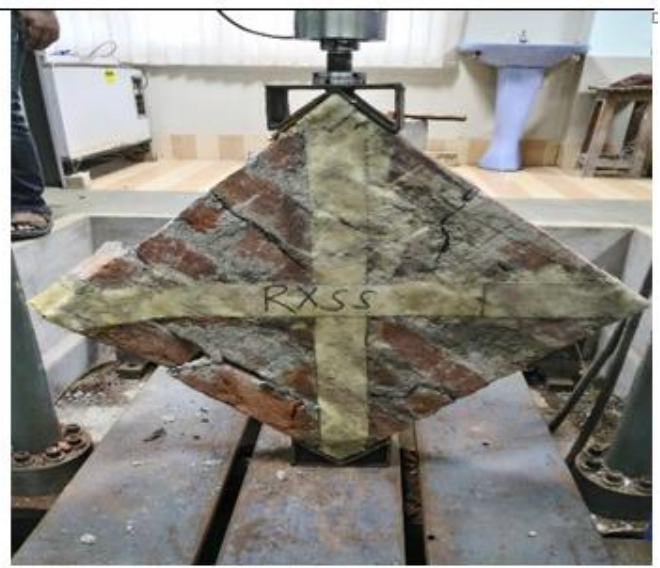

(b) RXSS

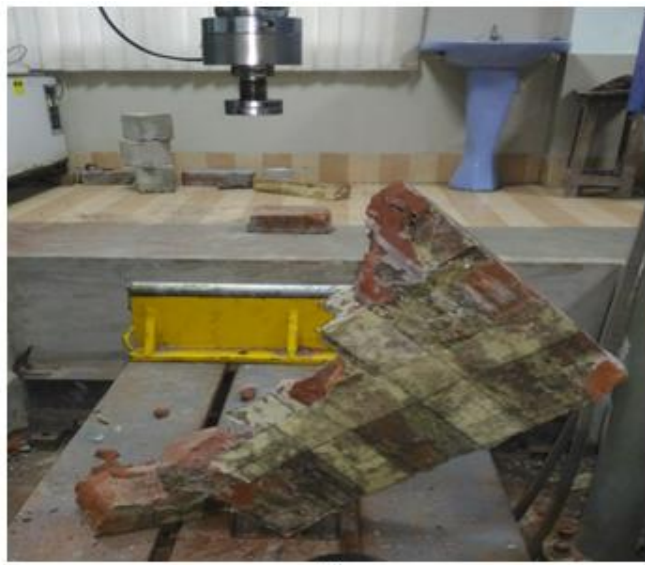

(d) RCBS

Fig.4. Failure modes of tested panels

The experimental results of the test specimens are discussed and compared in this section. Performance parameters of specimens are evaluated and compared to investigate the best retrofitting pattern. To observe the global behaviour of the specimens, load versus displacement along the compressed diagonal curves are plotted from experimental test results of one and both side retrofitted panels with the specimen un-retrofitted panel in Fig.5. It was observed that failure load is increased from diagonal and cross pattern with highest for the cross pattern. The Same pattern also observed for both side retrofitting. Un-retrofitted panels show a peak strength of $26.6 \mathrm{kN}$. GFRP has increased the peak strength of UR from $26.6 \mathrm{kN}$ to $40.0 \mathrm{kN}$ when retrofitted with one side while it goes up to $69.5 \mathrm{kN}$ when retrofitted with both side as compared to un-retrofitted specimens. Similarly, the stiffness is increased from diagonal and cross pattern with highest for the cross pattern. Further, it also observed that the stiffness value increases when retrofitted with both side as compared to un-retrofitted. 

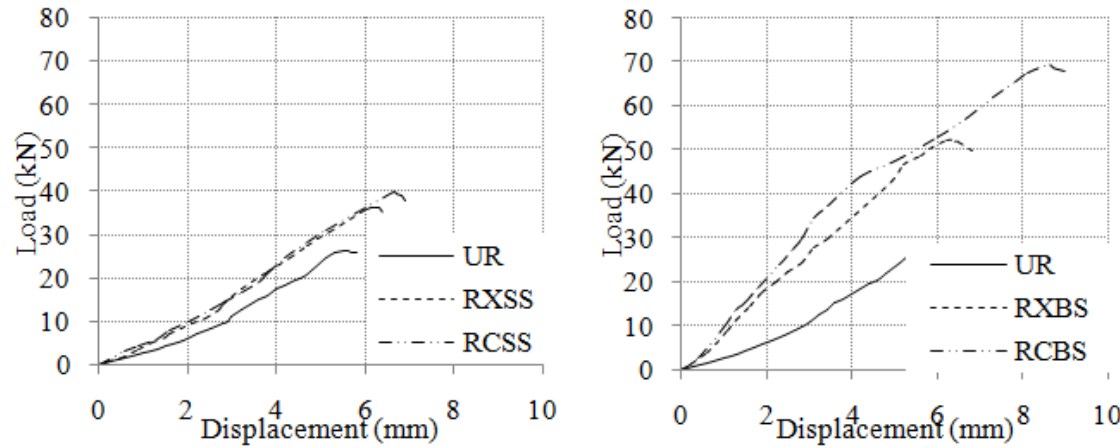

Fig.5. Diagonal compression experimental test results of un-retrofitted and retrofitted masonry panels: (a) one side retrofitted, (b) both side retrofitted

According to FEMA 356, 2000 the in-plane strength of the diagonal failure mode (shear failure mode) of existing and enhanced URM walls shall be taken in accordance with the following equation [13]:

$$
V_{d t}=S_{s} A \frac{L}{H} \sqrt{1+f_{a} / S_{s}}
$$

Where, $\mathrm{V}_{\mathrm{dt}}=$ in-plane strength of the diagonal failure mode (shear failure mode), $\mathrm{f}_{\mathrm{a}}=$ axial compressive stress due to gravity loads, $\mathrm{A}=$ cross-sectional area of the wall), $\mathrm{L}=$ length of the wall, $\mathrm{h}=$ height of the wall.

According to ASTM E 519, the Diagonal Shear strength for masonry panels is calculated as follows:

$\mathrm{S}_{\mathrm{s}}=\frac{0.707 \times \mathrm{P}}{\mathrm{A}}$

Where, $\mathrm{S}_{\mathrm{s}}=$ Diagonal Shear strength, MPa; $\mathrm{A}=$ cross sectional area of panel, $\mathrm{mm}^{2} ; \mathrm{P}=$ Crushing load, N.Further, cross sectional area (A) is calculated as follows:

$\mathrm{A}=\frac{\mathrm{L}+\mathrm{H}}{2} \times \mathrm{t} \times \mathrm{n}$

Where, $\mathrm{L}=$ length of panel, $\mathrm{mm} ; \mathrm{H}=$ height of panel, $\mathrm{mm} ; \mathrm{t}=$ thickness of panel, $\mathrm{mm} ; \mathrm{n}=$ percent of the gross area of the unit that is solid, expressed as a decimal.

The diagonal shear strength, In-plane strength is calculated with the help of equation (i), (ii) and (iii). The diagonal shear strength and increase in in-plane strength are given in Table 6.

Table.6. Performance parameter of the investigated walls

\begin{tabular}{|l|l|l|l|l|}
\hline $\begin{array}{l}\text { Retrofitting } \\
\text { pattern }\end{array}$ & Specimen & $\begin{array}{l}\text { Diagonal shear } \\
\text { strength, } \mathrm{S}_{\mathrm{S}}(\mathrm{MPa})\end{array}$ & $\begin{array}{l}\text { In plane strength } \\
(\mathrm{kN})\end{array}$ & $\begin{array}{l}\text { Increase in in-plane } \\
\text { strength over UR (\%) }\end{array}$ \\
\hline & UR & 0.25 & 71.74 & - \\
\hline \multirow{2}{*}{$\begin{array}{l}\text { One side } \\
\text { retrofitted }\end{array}$} & RXSS & 0.34 & 84.69 & 18.05 \\
\cline { 2 - 5 } & RCSS & 0.38 & 90.00 & 25.45 \\
\hline \multirow{2}{*}{$\begin{array}{l}\text { Both side } \\
\text { retrofitted }\end{array}$} & RXBS & 0.49 & 103.68 & 44.52 \\
\cline { 2 - 5 } & RCBS & 0.65 & 121.84 & 69.84 \\
\hline
\end{tabular}

It was observed that the in-plane strength of the retrofitted patterns increased from $18.05 \%$ to $25.45 \%$ when retrofitted with one side, while it goes up to $69.84 \%$ when retrofitted with both side as compared to unretrofitted specimens. Further, it also observed that the panel with cross retrofitting gives more strength as compared to other patterns. Similarly, the diagonal shear strength also increases with the same pattern.

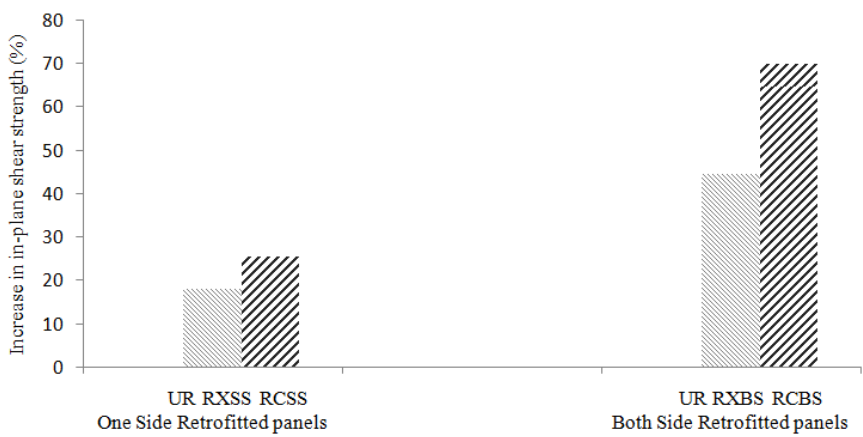

Fig.6. Comparative diagram of in-plane strength of one side and both side retrofitted panels 
Fig. 6 shows the comparative bar diagram of the in-plane strength of one side and both side retrofitted panels for the various retrofitting pattern. There is an increase of in-plane shear strength from diagonal and cross pattern with highest for the cross pattern. The Same pattern also observed for both side retrofitting while the bar chart shows higher increase in strength when compared to one side retrofitting.

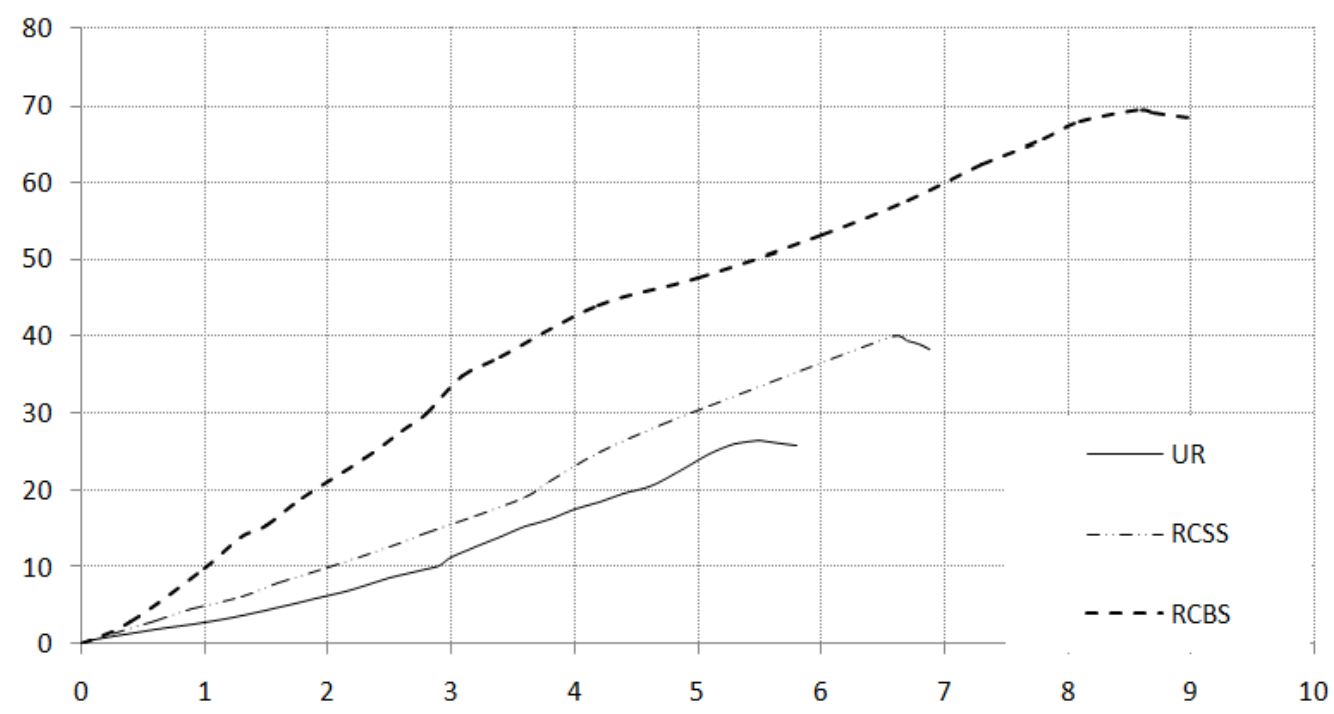

Fig.7. Experimental comparative load-displacement diagram for RCSS and RCBS

Fig. 7 represents load-displacement diagram for cross pattern for one and both side (RCSS and RCBS). It is observed that the stiffness value increases when retrofitted with both side. Un-retrofitted panels showed peak strength of $26.6 \mathrm{kN}$. Further, it also observed GFRP has increased displacement capacity also. The displacement at failure load increases of UR from $5.5 \mathrm{~mm}$ to $6.6 \mathrm{~mm}$ when retrofitted with one side while it goes up to $8.5 \mathrm{~mm}$ when retrofitted with both side as compared to un-retrofitted specimens.

\section{Conclusion}

The in-plane performances of brick masonry panels with different retrofitting patterns using GFRP, have been studied under diagonal compression test. The panels were retrofitted on one side and both sides with different geometric configurations. This experimental study demonstrates the effectiveness of glass fibre reinforced polymers (GFRPs) as new strengthening technology for unreinforced brick structures. The unretrofitted panel showed brittle behaviour whereas retrofitting increased its deformation capacity. The retrofitted specimens increased the failure load from $26.6 \mathrm{kN}$ (UR) to $69.5 \mathrm{kN}$. Further, it also observed GFRP has increased displacement capacity from $5.5 \mathrm{~mm}$ (UR) to $8.5 \mathrm{~mm}$. The ratio of the weight to the load-bearing capacity decreases from $3.2 \%$. to $2.1 \%$ with increases GFRP reinforcement (\%) when one side retrofitted, while it reduces further to $1.2 \%$ when both side retrofitted. It was observed that the in-plane strength of the retrofitted patterns increased from $18.05 \%$ to $69.84 \%$ when compared to un- retrofitted specimens. FRP retrofitting also increased the diagonal shear strength. It was observed that diagonal shear strength of the retrofitted panels increased from 0.25 $\mathrm{MPa}$ to $0.38 \mathrm{MPa}$ when retrofitted with one side, while it goes up to $0.65 \mathrm{MPa}$ when retrofitted with both side as compared to un-retrofitted specimens. Further, it also observed that the panel with cross retrofitting showed more efficiency in terms of shear strength, in-plane strength, stiffness and deformation capacity.

\section{References}

[1] R. P. Nanda, P Agarwal, and M Shrikhande, Frictional Base Isolation by Geotextiles for Brick Masonry Buildings, Geosynthetic International, 17 (1), 2010, 48-55.

[2] S. Khan, A. N. Khan, A. S. Elnashai, M. Ashraf, M. Javed, A. Naseer andB. Alam, Experimental seismic performance evaluation of unreinforced brick masonry buildings,Earthquake Spectra, 28 (3), 2012, 1269-1290.

[3] M. A. ElGawady,P. Lestuzzi and M. Badoux, Static cyclic response of masonry walls retrofitted with fibre-reinforced polymer,Journal of Composites for Construction, 11 (1), 2007, 50-61.

[4] A. Kalali andM. Z. Kabir, Cyclic behaviour of perforated masonry walls strengthened with glass fibre reinforced polymers,Scientia Iranica A,19 (2), 2012, 151-165.

[5] A. Smith and T. Redman,A critical review of retrofitting methods for unreinforced masonry structures, In: Proceedings of EWB-UK research conference, University of Bristol, 2009. 
[6] A. Reza, T. Ikemoto, M. Miyajima andA.Fallahi, A comparative study on seismic retrofitting methods for unreinforced masonry brick walls, In: Proceedings of the 15th world conference on earthquake engineering, Lisboa, 2012.

[7] A. Kalali and M. Z. Kabir, Experimental response of double-wythe masonry panels strengthened with glass fibre reinforced polymers subjected to diagonal compression tests,Engineering Structures, 39, 2012, 24-37.

[8] H. Mahmood and J. M. Ingham, Diagonal compression testing of FRP-retrofitted unreinforced clay brick masonry wallettes,Journal of Composites for Construction, 15(5), 2011, 810-820.

[9] S. M. Umair, M. Numada, and K. Meguro, In plane behaviour of polypropylene and FRP retrofitted brick masonry wallets under diagonal compression test,In: Proceedings of the 15th world conference on earthquake engineering, Lisboa, 2012.

[10] American Society for Testing and Materials (ASTM), Standard test method for diagonal tension (shear) in masonry assemblages, E 519, 2001.

[11] IS 3495 (Part 1): 1992, Methods of tests of burnt clay building bricks, Bureau of Indian Standards, New Delhi.

[12] American Society for Testing and Materials (ASTM), Standard test method for compressive strength of hydraulic cement mortars, C 109/C 109M, 1999.

[13] FEMA 356, Pre-standard for the seismic rehabilitation of buildings, Washington: Federal Emergency Management Agency, 2000. 